\title{
Palmitic Acid-Pluronic F127-Palmitic Acid Pentablock Copolymer as a Novel Nanocarrier for Oral Delivery of Glipizide
}

\author{
Glipizidin Oral Uygulanması için Yeni Bir Nanotaşıyıcısı Olarak Palmitik Asit \\ - Pluronic F127 - Palmitik Asit Pentablok Kopolimeri
}

\author{
(D) Vipan Kumar KAMBOJ, (D) Prabhakar Kumar VERMA* \\ Maharshi Dayanand University, Department of Pharmaceutical Sciences, Rohtak, India
}

\begin{abstract}
Objectives: The aim of the present study was to develop nanotechnology-based oral formulations of glipizide to enhance the bioavailability and eliminate the frequent oral administration of the conventional dosage form. Glipizide is an antidiabetic drug with a short biological half-life and limited oral bioavailability. Novel palmitic acid-pluronic F127-palmitic acid (PA-F127) pentablock copolymer-based prolonged release glipizide nanoparticles (GNs) were prepared and screened for in vitro and in vivo studies.

Materials and Methods: GNs were prepared using a novel PA-F127 pentablock copolymer by solvent evaporation technique. The prepared nanoparticles were evaluated for particle size, polydispersity index (PDI), zeta potential, entrapment efficiency, percentage yield, and drug excipient compatibility using fourier transform infrared spectroscopy (FTIR) and differential scanning calorimeter (DSC) analysis, X-ray diffraction, scanning electron microscopy, in vitro drug release studies, stability studies, and in vivo pharmacokinetic studies.

Results: The results of FTIR and DSC analysis revealed the absence of drug-excipient interactions. The optimized GN1 had particle size $242.60 \pm 4.20$ $\mathrm{nm}, \mathrm{PDI} 0.171 \pm 0.014$, and zeta potential $-21.41 \pm 0.462 \mathrm{mV}$. The prepared nanoparticles were spherical and showed semi-amorphous characteristics. The in vitro release studies showed $34.43 \pm 4.8 \%$ drug was released in the first $8 \mathrm{~h}$ and $56.11 \pm 4.12 \%$ glipizide was released further over $24 \mathrm{~h}$. The GN1 was found to be stable at $5 \pm 3^{\circ} \mathrm{C}$ for up to 3 months. Pharmacokinetic studies showed that the orally administered GN1 was superior with $C_{\text {max }}$ 2.35-fold, $t_{\max } 1.6$-fold, area under the curve $\left(A \cup C_{0 \rightarrow \infty}\right.$ ) 3.3-fold, and mean residence time 1.2-fold as compared to pure glipizide ( $p<0.05$ ).

Conclusion: The bioavailability of the newly developed GN1 was successfully increased and the problem of frequent oral administration with the conventional dosage form can be overcome for diabetes treatment.
\end{abstract}

Key words: Glipizide, nanoparticles, palmitic acid, pluronics, bioavailability

öz

Amaç: Bu çalışmanın amacı, glipizidin biyoyararlanımı artırmak ve geleneksel dozaj formunun oral yoldan sık sık verilmesini elimine etmek için nanoteknoloji bazlı oral formülasyonlarını geliștirmektir. Glipizide, biyolojik olarak kısa yarı ömrü ve sınırlı oral biyoyararlanımı olan antidiyabetik bir ilaçtır. Yeni palmitik asit-pluronik F127-palmitik asit (PA-F127) pentablok kopolimer bazlı uzun süreli salım yapan glipizid nanopartikülleri (GNs) in vitro ve in vivo çalışmalar için hazırlanmış ve taranmıştır.

Gereç ve Yöntemler: GN'ler yeni PA-F127 pentablok kopolimer kullanılarak solvent buharlaştırma yöntemi ile hazırlanmıştır. Hazırlanan nanopartiküller, partikül büyüklüğü, polidispersite indeksi (PDI), zeta potansiyeli, yükleme etkinliği, yüzde verimi ve fourier transform kızılötesi spektroskopisi (FTIR) ve diferansiyel tarama kalorimetresi (DSC) analizi, X-ışını kırınımı kullanılarak etken madde ile eksipiyan geçimliliği, taramalı elektron mikroskobu, in vitro etken madde salım çalışmaları, stabilite çalışmaları ve in vivo farmakokinetik çalışmalar değerlendirildi.

Bulgular: FTIR ve DSC analizlerinin sonuçları, etken madde-eksipiyan etkileşimlerinin olmadığını göstermiştir. Optimize edilmiş GN1'in, partikül büyüklüğü $242.60 \pm 4.20 \mathrm{~nm}$, PDI $0.171 \pm 0.014$ ve zeta potansiyeli $-21.41 \pm 0.462 \mathrm{mV}$ idi. Hazırlanan nanopartiküller küreseldi ve yarı amorf özellikler göstermiştir. In vitro salım çalışmaları, ilk 8 saatte \%34.43 4.8 etken madde salındığını ve 24 saat içinde $56.11 \pm \% 4.12$ glipizid salındığını göstermiştir. GN1'in $5 \pm 3^{\circ} \mathrm{C}^{\prime}$ de 3 aya kadar stabil olduğu bulunmuştur. Farmakokinetik çalışmalar, oral yoldan verilen GN1'in, saf glipizide göre 2.35 kat $C_{\text {max' }} 1.6$ kat $t_{\text {max }}$ 3.3 kat eğri altındaki alan ( $A \cup C_{0 \rightarrow \infty}$ ) ve 1.2 kat ortalama kalış süresi ile daha üstün olduğunu göstermiştir ( $p<0.05$ ).

Sonuç: Yeni geliştirilen GN1'in biyoyararlanımı başarılı bir şekilde arttırılmıştır ve diyabet tedavisi için ticari dozaj formu ile sık sık oral uygulama sorunu aşılabilmiştir.

Anahtar kelimeler: Glipizid, nanopartiküller, palmitik asit, pluronikler, biyoyararlanım

*Correspondence: E-mail: vermapk422@rediffmail.com, Phone: +919992581437 ORCID-ID: orcid.org/0000-0002-1769-6484

Received: 09.03.2018, Accepted: 16.05.2018

Turk J Pharm Sci, Published by Galenos Publishing House. 


\section{INTRODUCTION}

Glipizide is a potential second-generation sulfonylurea derivative belonging to Biopharmaceutical Classification System Class-II drugs. It is commonly utilized as an oral hypoglycemic agent for the treatment of type II diabetes mellitus.,2 Glipizide is the most effective insulin secretagogue and presents fewer side effects compared to the first-generation drugs. ${ }^{3}$ It is a weak acid with a pka value of 5.9 and is better absorbed from acidic medium. Due to the very low $\mathrm{pH}$ level of glipizide, its aqueous solubility is negligible, which causes discrepancies in bioavailability. ${ }^{4}$ After absorption from the gastrointestinal tract, glipizide reduces the blood glucose levels in $30 \mathrm{~min}$ and peak concentration of the drug is reached within 1-3 h. ${ }^{3}$ It is rapidly eliminated from the body due to its small biological half-life $(3.4 \pm 0.7 \mathrm{~h})$ and hence the drug needs frequent oral administration in 2 or 3 doses of 2.5 to $10 \mathrm{mg}$ per day. ${ }^{5}$ Due to the poor solubility of glipizide, researchers have investigated several drug delivery systems including a solid self-nanoemulsifying drug delivery system, ${ }^{2}$ microspheres, ${ }^{5}$ poly(lactic-co-glycolic acid), Eudragit nanoparticles, ${ }^{6}$ cyclodextrin complex, ${ }^{7,8}$ chitosan and xanthan beads, ${ }^{9}$ and nanosuspension ${ }^{10}$ to increase the solubility and bioavailability of glipizide. Nanotechnology-based drug delivery systems with the use of biodegradable polymers seem to be most convenient for the delivery of any drug due to negligible chances of toxicity and overall improved therapeutic properties."

Pluronics are A-B-A type triblock nonionic, biodegradability copolymers listed in the British and US Pharmacopoeia as excipients and extensively used in drug delivery systems. ${ }^{10,12}$ Due to the amphiphilic nature of Pluronics, they are selfassembled into micelles above the critical micelle concentration in an aqueous solvent.13 The critical micelle concentration (CMC) value of Pluronic F127 was observed in the range 0.260.8 wt \%. The high CMC value indicates the dissociation of nanoparticles occurs before the target site is reached. This problem can be overcome using mixed polymers. The modified block copolymers like stearic acid-coupled F127 nanoparticles of doxorubicin ${ }^{12}$ and Pluronic/poly(lactic acid) vesicles for oral insulin deliver ${ }^{14}$ have been investigated. These studies inspired us to go further to explore the application of Pluronics in a nanotechnology-based oral drug delivery system for glipizide.

In the present study, we aimed to develop glipizide nanoparticles (GNs) with better bioavailability that overcome the problem of frequent dose administration. We prepared orally active GNs using PA-F127 copolymer that were optimized for physicochemical properties and evaluated their pharmacokinetic parameters in rats. We also analyzed the stability of the $\mathrm{GNs}$ at $5 \pm 3^{\circ} \mathrm{C}$ and $25^{\circ} \mathrm{C}$ over 3 months.

\section{MATERIALS AND METHODS}

\section{Materials}

Pharmaceutical grade glipizide was purchased from Swapnroop Drugs and Pharmaceuticals, Aurangabad, India. Palmitic acid (PA), Pluronic F127, and polyvinyl alcohol (PVA) were procured from Sigma-Aldrich, India. The other chemicals and solvents used were of analytical grade and were purchased from Molychem, Mumbai.

\section{Synthesis of PA-F127 pentablock copolymer}

PA $(15 \mathrm{~g})$ and $15 \mathrm{~g}$ of Pluronic F127 $(15 \mathrm{~g})$ were added to a $100 \mathrm{~mL}$ round bottom flask and the mixture was heated with constant stirring to yield a well-mixed molten phase and it was reacted at $160^{\circ} \mathrm{C}$ for $6 \mathrm{~h}$. The PA-F127 copolymer was recovered by mixing the resulting solution into an ethyl acetate/petroleum ether 1:1 $(\mathrm{v} / \mathrm{v})$ solution to eliminate the unreacted PA by filtration. The PA-F127 copolymer was obtained by evaporating the organic solvent at room temperature and dried at $25^{\circ} \mathrm{C}$ under vacuum for $24 \mathrm{~h}$. The synthesized copolymer structure was confirmed by the spectrum of fourier transform infrared spectroscopy (FTIR) (Bruker 1-206-0280, KBr pellets) and ${ }^{~} \mathrm{H}$ NMR (Bruker Model Advance II 400; $400 \mathrm{MHz}$ ) spectroscopy.

\section{Preparation of glipizide loaded PA-F127 nanoparticles}

GNs were fabricated by solvent evaporation technique using PA-F127 and PVA polymeric systems. A mixture of chloroform and methylene chloride $(1: 1 \mathrm{v} / \mathrm{v})$ was prepared and glipizide was dissolved in it. The PA-F127 copolymer was dissolved in chloroform. The copolymer solution was added to glipizide solution drop by drop with continuous stirring. Next $1.0 \mathrm{~mL}$ of the aqueous phase of PVA (2\%) was added dropwise to the organic mixture of drug and copolymer with continuous homogenization (12000 rpm; IKA T25 ultra homogenizer) followed by stirring $(700 \mathrm{rpm}$ ) for $3 \mathrm{~h}$ and the nanosuspension obtained was stored in vacuum desiccators overnight at room temperature in order to remove the remaining organic solvents. The un-incorporated glipizide aggregates were removed through filtration using Whatman paper no. 1. The filtrate was centrifuged (14000 rpm; Remi, India) and sediment containing nanoparticles was separated and dried by lyophilization. ${ }^{12,15}$

\section{Characterization of prepared GNs}

\section{Particle size, polydispersity index, and zeta potential}

The average particle size, polydispersity index (PDI), and zeta potential of the GNs were evaluated using a Zetasizer NanoZS (Malvern Instruments, UK). Then $0.5 \mathrm{mg} / \mathrm{mL}$ suspension was prepared in Milli-Q water and analyzed to determine these parameters. The results were described as mean \pm standard deviation for three replicates. ${ }^{16}$

\section{Entrapment efficiency and percentage yield}

Accurately weighed GNs were dissolved in methylene chloride $(20 \mathrm{~mL}$ ). This solution was added to $100 \mathrm{~mL}$ of freshly prepared phosphate buffer $(\mathrm{pH}$ 7.4) and continuously stirred to extract the glipizide in it. The methylene chloride evaporates during the stirring process. ${ }^{17}$ The undissolved content was removed by centrifugation at $10000 \mathrm{rpm}$ (Remi, India), the supernatant was filtered, and the amount of glipizide was assessed using a ultraviolet-Vis spectrophotometer (Lab India $3000^{+}$) at 225 $\mathrm{nm}$. Drug entrapment efficiency (\%) and percentage yield were calculated using Equation 1 and 2, respectively.

$$
\underset{\text { efficiency }}{\text { Entrament }}(\%)=\frac{\text { Amount of glipizide in nanoparticles }}{\text { Amount of glipizide used in formulation }} \times 100 \text { Equation } 1
$$




$$
\text { Percentage yield }=\frac{\text { Total nanoparticles weght }}{\text { Total solid weight }} \times 100 \text { Equation } 2
$$

\section{FTIR studies}

The interactions between glipizide and excipients were analyzed using FTIR. FTIR spectra of the PA-F127 copolymer, PVA, pure glipizide, physical mixture, and GN1 were taken in $\mathrm{KBr}$ pellets using a Bruker (1-206-0280 with software: OPUS-7.2.139.1294) spectrometer and the values of $\lambda$ max were reported in $\mathrm{cm}^{-1}$ (range: 400-4000).

\section{Differential scanning calorimetric analysis}

The samples used for FTIR studies were selected for the analysis of thermal properties by using DSC Q10 V9.9, US. The instrument was calibrated using indium as standard. The samples were sealed in aluminum pans with lids and heated at a rate of $10^{\circ} \mathrm{C} / \mathrm{min}$ under a nitrogen environment $(60 \mathrm{~L} / \mathrm{min})$. The empty aluminum pan was used as a reference. The heat flow was recorded from 35 to $280^{\circ} \mathrm{C}$.

\section{$X$-ray diffraction analysis}

$X$-ray diffraction (XRD) analysis of selected samples was carried out using a Rigaku Miniflex-600 diffractometer. A Cu $\mathrm{K} \alpha$ source operation ( $40 \mathrm{kV}, 15 \mathrm{~mA}$ ) was used. The diffraction pattern of samples was recorded over a $2 \theta$ angular range of 10-70.

\section{Surface morphological studies}

The surface morphology of the physical mixture and bestoptimized batch was examined by field emission scanning electron microscopy (FE-SEM; JEOL-JSM-7600F, Japan). The samples were dispersed on metallic stubs and then gold coating was done using an ion-sputtering machine. These samples were vacuum dried before the examination.

\section{In vitro dissolution studies}

In vitro dissolution studies were performed for the optimized GN1 batch and pure glipizide by modified dialysis sac method. ${ }^{18}$ Accurately weighed GN1 suspension (equivalent to $5 \mathrm{mg}$ of glipizide) and pure glipizide suspension ( $5 \mathrm{mg}$ ) were placed in dialysis membrane bags (12-14 kDa cut-off, HiMedia, India) and tied with dialysis clips. The dialysis bags were immersed in separate conical flasks containing $150 \mathrm{~mL}$ of $0.1 \mathrm{M}$ phosphate buffer solution $(\mathrm{pH}$ 7.4). The conical flasks were stirred at $100 \mathrm{rpm}$ with temperature $37.0 \pm 0.5^{\circ} \mathrm{C}$. At fixed time intervals, an aliquot of $1 \mathrm{~mL}$ was withdrawn from the conical flask and replenished with $1 \mathrm{~mL}$ of fresh phosphate buffer and the assay was performed using a UV-Vis spectrophotometer (Lab India $\left.3000^{+}\right)$at $225 \mathrm{~nm}$.

\section{Stability studies}

It is important to have an insight into the stability of prepared nanoparticles. The GN1 suspension was kept in a colored glass bottle at $5 \pm 3^{\circ} \mathrm{C}$ and $25^{\circ} \mathrm{C}$ for short-term stability studies. An aliquot of GN1 samples was taken after 1 and 3 months. These samples were analyzed for any possible change in particle size, PDI, zeta potential, entrapment efficiency, and color of suspension.

\section{Animals}

In vivo studies were accomplished in female Wistar albino rats weighing between 250 and $300 \mathrm{~g}$. The rats were procured from the Lala Lajpat Rai University of Veterinary and Animal Sciences, Hisar, India. The rats were kept in polypropylene cages and housed in the central animal house of Maharshi Dayanand University, Rohtak, under standard environmental conditions $\left(23.0 \pm 1^{\circ} \mathrm{C}, 55 \pm 5 \%\right.$ humidity, and $12 \mathrm{~h} / 12 \mathrm{~h}$ light/dark cycle). The animals had ad libitum access to standard animal diet and water. The protocols of the animal studies were permitted by the Institutional Animal Ethical Committee (IAEC 151/57 dated 30/03/2015) and the experiments were performed according to CPCSEA guidelines.

\section{Pharmacokinetic evaluation in Wistar albino rats}

The overnight fasted rats $(n=6)$ were treated with a single oral dose of freshly prepared GN1 carrying $1.5 \mathrm{mg}$ of drug (group I) and pure glipizide suspension was given in group II $(1.5 \mathrm{mg} /$ $\mathrm{kg}$ b.w.). The blood samples were withdrawn at different time intervals $(0,0.5,1,2,3,4,6,9,12$, and 24 h) through the tail vein using heparinized tubes. The plasma was separated by centrifugation (Plasto Crafts, India) and stored at $-20^{\circ} \mathrm{C}$ until further examination. A rat plasma sample of $0.1 \mathrm{~mL}$ and $0.1 \mathrm{~mL}$ of $0.1 \mathrm{~N} \mathrm{HCl}$ were vortexed for $3 \mathrm{~min}$ and then $3 \mathrm{~mL}$ of benzene was added for the precipitation of plasma proteins. The mixture was smoothly shaken using a cyclo-mixer for $5 \mathrm{~min}$ followed by centrifugation for $10 \mathrm{~min}$ at $6000 \mathrm{rpm}$ and the precipitates were removed by syringe filter $(0.22 \mu \mathrm{m})$. The organic phase was evaporated under a nitrogen environment and the residue was thawed in $0.1 \mathrm{~mL}$ of mobile phase by vortex mixing. An aliquot of $20 \mu \mathrm{L}$ was injected into the column of the reverse phase-high performance liquid chromatographic (HPLC) by auto-sampler.

Glipizide in the rat blood plasma was estimated by HPLC using an earlier reported bioanalytical method. ${ }^{19}$ The pharmacokinetic studies were performed on a Dionex UHPLC ultimate 3000 RS containing a pump, auto-sampler, column compartment (column: Agilent; $250 \mathrm{~mm} \times 4.6 \mathrm{~mm}$; particle size $5 \mu \mathrm{m}$ ), and diode array detector. The data acquisition was achieved through Chromoleon 6.8 software. The monobasic potassium dihydrogen orthophosphate buffer $(20 \mathrm{mM} ; \mathrm{pH} 3.5)$ and acetonitrile were used as mobile phase $(65: 35 \mathrm{v} / \mathrm{v})$. The mobile phase was filtered through a membrane filter $(0.22 \mu \mathrm{m})$ and sonicated. The flow rate was kept at $1 \mathrm{~mL} / \mathrm{min}$ and the total run time of the method was set at $15 \mathrm{~min}$. The effluent was monitored at $225 \mathrm{~nm}$.

\section{Statistical analysis}

The pharmacokinetic data were compared by Student's paired t-test using GraphPad Prism 7 software. P values $<0.05$ were considered significant. 


\section{RESULTS AND DISCUSSION}

Characterization of PA-F127 pentablock copolymer

The carboxylic group of PA was esterified with the hydroxyl groups of Pluronic F127 (Scheme 1). The structure of PA-F127 copolymer was determined by ${ }^{1} \mathrm{H}$ NMR spectroscopy in $\mathrm{CDCl}_{3}$ and the $\delta$ (ppm) values of different groups are shown in Table 1. The FTIR spectra of the synthesized copolymer having an ester band ( $C=0$ stretching vibration) at $1700.77 \mathrm{~cm}^{-1}$ were observed, which confirmed the reaction between PA and F127.

\section{Preparation of glipizide loaded polymeric nanoparticles}

The GNs were fabricated by the solvent evaporation method with different glipizide to copolymer ratios (glipizide:PA-F127; 1:1, 1:2, 1:3, and 2:1 w/w) and a fixed concentration of PVA. By this technique, nanoparticles are easily prepared compared to the other methods. A mixture of PA-F127 copolymer and glipizide in organic solvent forms the organic phase. Aqueous phase comprising PVA was added drop by drop to the organic phase. The organic solvents used in these nanoparticles quickly partitioned into the exterior aqueous phase and PVA precipitated around copolymer encapsulated glipizide particles. Evaporation of the entrapped organic solvents leads to the formation of glipizide loaded polymeric nanoparticles. ${ }^{15}$

\section{Optimization parameters of prepared GNs}

The GNs were optimized on the basis of morphological properties (in terms of particle size and surface characteristics), entrapment efficiency, and percentage yield. Particle size analysis used to characterize the nanoparticles and it helps us to understand the dispersion and aggregation. ${ }^{20}$ With the reduction in particle size, enhancement of surface area and attractive forces between the particles generate the possibility

Table 1. Major features of 1H NMR spectra of the PA-F127 copolymer in $\mathrm{CDCl}_{3}$

\begin{tabular}{ll}
$\delta$ (ppm) & Assigned \\
\hline $\mathrm{CH}_{2}-\mathrm{O}$ in PEO & $3.68-3.66$ \\
\hline $\mathrm{CH}_{2} \mathrm{CH}_{2}-\mathrm{O}$ in PEO & $2.37-2.34$ \\
\hline $\mathrm{CH}_{2} \mathrm{CH}\left(\mathrm{CH}_{3}\right)-\mathrm{O}$ in PEO & $1.66-1.62$ \\
\hline $\mathrm{CH}_{2} \mathrm{CH}\left(\mathrm{CH}_{3}\right)-\mathrm{O}$ in PEO & $1.31-1.27$ \\
\hline $\mathrm{CH}_{2}$ in PA & $1.17-1.14$ \\
\hline
\end{tabular}

PEO: Polyethylene oxide, PA: Palmitic acid of aggregation. To overcome such aggregation problems, the use of a surfactant in the nanoparticle preparation becomes essential. PVA can encapsulate the nanoparticles and also work as a surfactant by reducing the aggregation of nanoparticles, which keeps them suspended in solution after formation, and also re-suspension of lyophilized nanoparticles becomes easy. ${ }^{15,21}$ The zeta potential of the particles is a significant characteristic that can demonstrate particle stability. The higher the magnitude of zeta potential, irrespective of the charge type (positive or negative), the higher stability is anticipated. ${ }^{20,22}$

Entrapment efficiency and percentage yield are the targets of modern nanotechnology-based drug development. Generally, those excipients are selected that can entrap the maximum amount of drug and give the best yield along with other significant parameters. Higher drug entrapment leads to a reduction in drug loss during the manufacturing process. ${ }^{22,23}$

The glipizide to PA-F127 copolymer ratios critically affect particle size as well as other studied parameters. The optimization data of the GNs (Table 2) exhibited that the nanoparticles produced were of submicron size ranging from 242.6 to $891.2 \mathrm{~nm}$. The zeta potential and PDI values varied between 0.171 and 0.556 and between -8.03 and $-21.41 \mathrm{mV}$, respectively. The ranges of entrapment efficiency and percentage yield were $35.42 \%$ to $81.13 \%$ and $23.2 \%$ to $76.4 \%$, respectively.

Based on the morphological properties, entrapment efficiency, and percentage yield, among the five batches, 1:1 ratio (GN1) was chosen as the optimized one. The above parameters in the other four batches (GN2, 3, 4, and 5) were less valuable and hence were not selected for further studies. In batch GN5, a slight improvement in particle size, entrapment efficiency, and percentage yield was observed over batches GN2, 3, and 4 . This happened due to the change in the ratio of drug to copolymer. These preparation trials were performed three times, for reproducibility and uniformity of the results. The

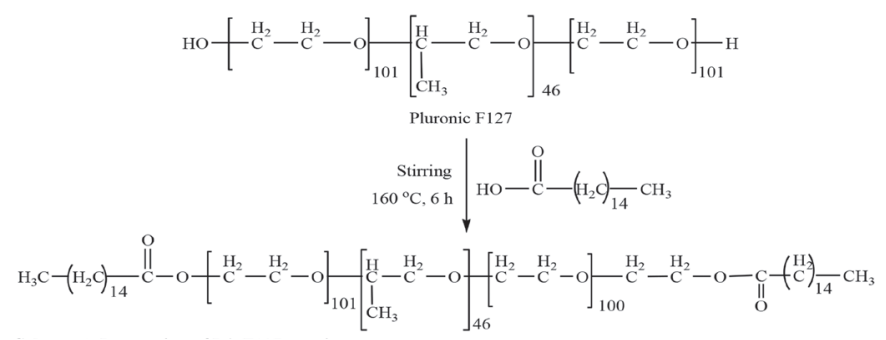

Scheme 1. Preparation of PA-F127 copolymer

Table 2. Evaluation parameters of prepared GNs

\begin{tabular}{llllllc} 
Batch & Glipizide:PA-F127 (w/w) & Particle size $(\mathrm{nm})$ & PDI & Zeta potential (mV) & Entrapment efficiency (\%) & Yield (\%) \\
\hline GN1 & $1: 1$ & $242.60 \pm 4.20$ & $0.171 \pm 0.0143$ & $-21.41 \pm 0.462$ & $81.13 \pm 3.12$ & $76.40 \pm 2.23$ \\
\hline GN2 & $1: 2$ & $630.46 \pm 4.05$ & $0.556 \pm 0.0362$ & $-16.33 \pm 0.153$ & $60.41 \pm 4.41$ & $59.31 \pm 4.22$ \\
\hline GN3 & $1: 3$ & $721.30 \pm 6.77$ & $0.328 \pm 0.0238$ & $-10.23 \pm 0.513$ & $50.30 \pm 3.34$ & $49.84 \pm 3.41$ \\
\hline GN4 & $1: 4$ & $891.20 \pm 7.80$ & $0.471 \pm 0.0264$ & $-8.03 \pm 0.737$ & $35.42 \pm 1.94$ & $23.20 \pm 3.45$ \\
\hline GN5 & $2: 1$ & $540.24 \pm 3.51$ & $0.391 \pm 0.0211$ & $-11.5 \pm 0.561$ & $70.60 \pm 2.51$ & $66.34 \pm 4.14$ \\
\hline
\end{tabular}

$\mathrm{n}=3$, mean values \pm standard deviation, PDI: Polydispersity index, GN: Glipizide nanoparticles 
particle size and zeta potential analysis of the optimized batch GN1 are shown in Figure 1.

\section{FTIR analysis}

The FTIR spectra provide a distinct idea about the interaction(s) between diverse functional groups existing in drugs and excipients. ${ }^{24,25}$ The possible interactions between PA-F127, PVA, glipizide, physical mixture, and optimized GN1 were investigated by comparing the FTIR peaks (Figure 2).

The IR spectra of pure glipizide exhibited peaks at $3250.44 \mathrm{~cm}^{-1}$ (-NH stretching), $2941.02 \mathrm{~cm}^{-1}$ (C-H stretching), $1690.44 \mathrm{~cm}^{-1}$ ( $\mathrm{C}=\mathrm{O}$ stretching), $1649.88 \mathrm{~cm}^{-1}\left(-\mathrm{CONH}\right.$ - stretching), $1591.28 \mathrm{~cm}^{-1}$ $\left(\mathrm{C}=\mathrm{C}\right.$ aromatic stretching), $1461 \mathrm{~cm}^{-1}(\mathrm{C}-\mathrm{H}$ aromatic bending), and 1337.27 and $1160.14 \mathrm{~cm}^{-1}(\mathrm{O}=\mathrm{S}=\mathrm{O})$, which are also detected in the physical mixture and GN1. No significant shift in peaks were detected in the physical mixture or optimized GN1 as
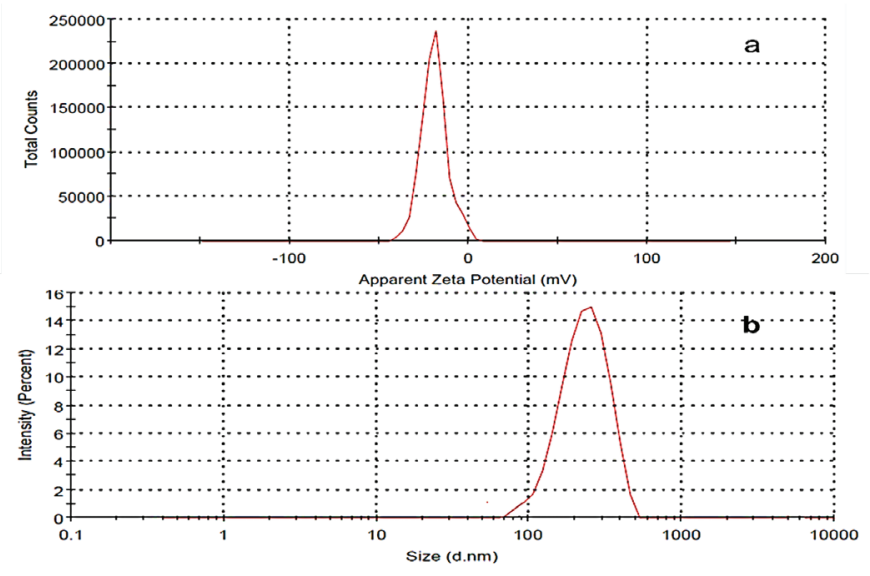

Figure 1. (a) Zeta potential and (b) particle size analysis of GN1

GN: Glipizide nanoparticles
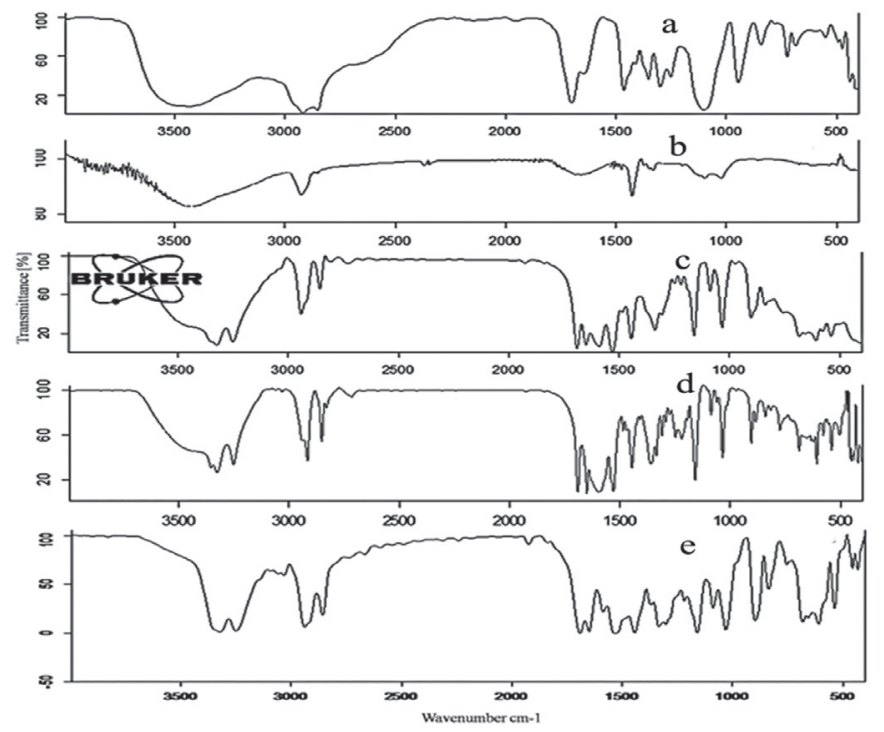

Figure 2. FTIR spectra of (a) PA-F127, (b) PVA, (c) pure glipizide, (d) physical mixture, and (e) GN1

FTIR: Fourier transform infrared spectroscopy, PVA: Polyvinyl alcohol,

GN: Glipizide nanoparticles compared to the spectra of PA-F127, PVA, and pure glipizide. This indicates that the glipizide and excipients used were compatible and suitable for the current investigation.

\section{DSC analysis}

It was found to be useful in the examination of the thermal properties of the nanoparticles, providing quantitative and qualitative information about the physicochemical state of the drug inside the nanoparticles as well as drug-polymer interactions. $^{26}$

A characteristic sharp endothermic peak at $212.18^{\circ} \mathrm{C}$ was observed for pure glipizide (Figure $3 \mathrm{c}$ ) that was absent in PA-F127 (Figure 3a) copolymer. PVA (Figure 3b) showed an endothermic peak at $215.31^{\circ} \mathrm{C}$ that overlapped with the glipizide peak in the physical mixture (Figure 3d) and GN1 (Figure 3e). A close look at the overlay in Figure 3 suggests that no significant shift in endothermic peaks was detected. Hence, there was no interaction between glipizide and polymeric excipients. The selection of excipients was done on the basis of the results of FTIR and DSC analysis and further studies were extended.

\section{$X R D$ studies}

The XRD patterns of the PA-F127 copolymer (Figure 4a) and PVA (Figure 4b) showed a diffused spectrum having fewer peaks and suggested a semi-amorphous nature. The XRD patterns of glipizide showed several sharp peaks (Figure 4c) that were found to be in line with a previous report. ${ }^{27}$ The characteristic sharp diffraction peaks due to pure glipizide and the diffused peaks of PA-F127 copolymer and PVA can be seen in the physical mixture (Figure $5 \mathrm{~d}$ ). After being formulated into nanoparticles, the XRD pattern of GN1 showed less sharp peaks (Figure $5 e$ ) with reduced intensity and had a partially amorphous nature. This decreased intensity shows the reduced crystalline properties of the drug. ${ }^{28}$

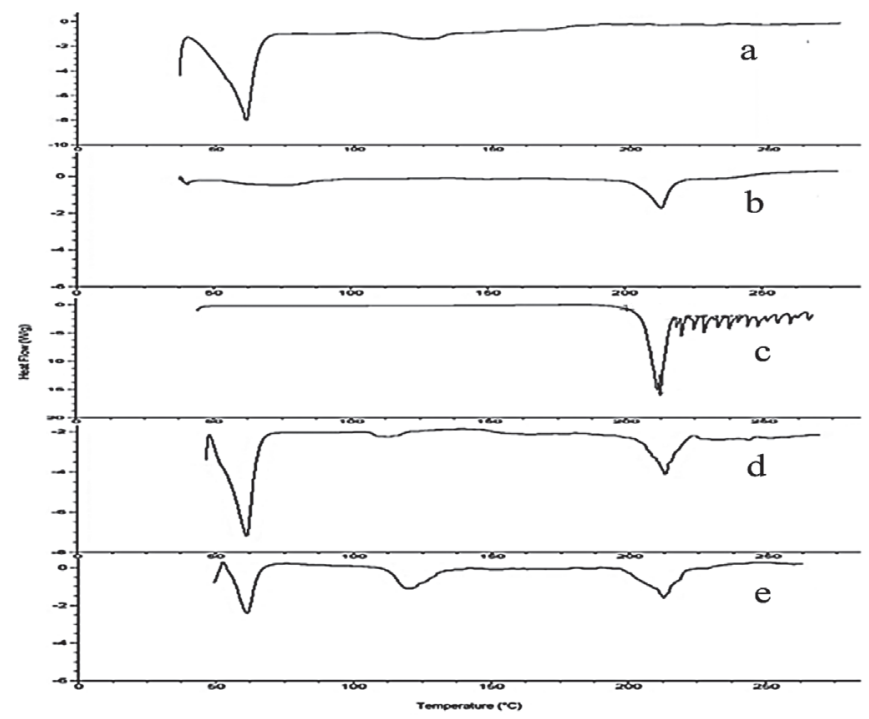

Figure 3. DSC thermograms of (a) PA-F127, (b) PVA, (c) pure glipizide, (d) physical mixture, and (e) GN1

DSC: Differential scanning calorimeter, PVA: Polyvinyl alcohol, GN: Glipizide nanoparticles 


\section{Surface morphology by SEM}

Smooth surfaced rectangular crystals of glipizide in the physical mixture (Figure $5 \mathrm{a}$ ) can be seen clearly, which were not visible in optimized GN1 (Figure 5b). The GN1 showed smooth and spherical nanoparticles, indicating that the glipizide becomes encapsulated in the polymeric matrix. This smooth surface property of nanoparticles demonstrated the complete removal of solvents from the GNs and was a sign of good quality. ${ }^{29}$

\section{In vitro studies}

The in vitro release of the glipizide from GN1 first showed burst release followed by sustained release (Figure 6). The release of glipizide from GN1 at 8 and $24 \mathrm{~h}$ was $34.43 \pm 4.8 \%$ and $56.11 \pm 4.64 \%$, respectively, whereas in the same time interval $53.1 \pm 4.6$ and $92.1 \pm 4.12 \%$ drug was released from pure glipizide. The initial burst release of glipizide from GN1 may have been due to the loosely associated drug on the interface of the polymeric matrix. The drug incorporated into the inner core compartment stayed firmly inside the nanoparticles, showing a sustained drug release pattern. ${ }^{12}$

\section{Stability studies}

Three-month stability studies were performed for GN1 at two

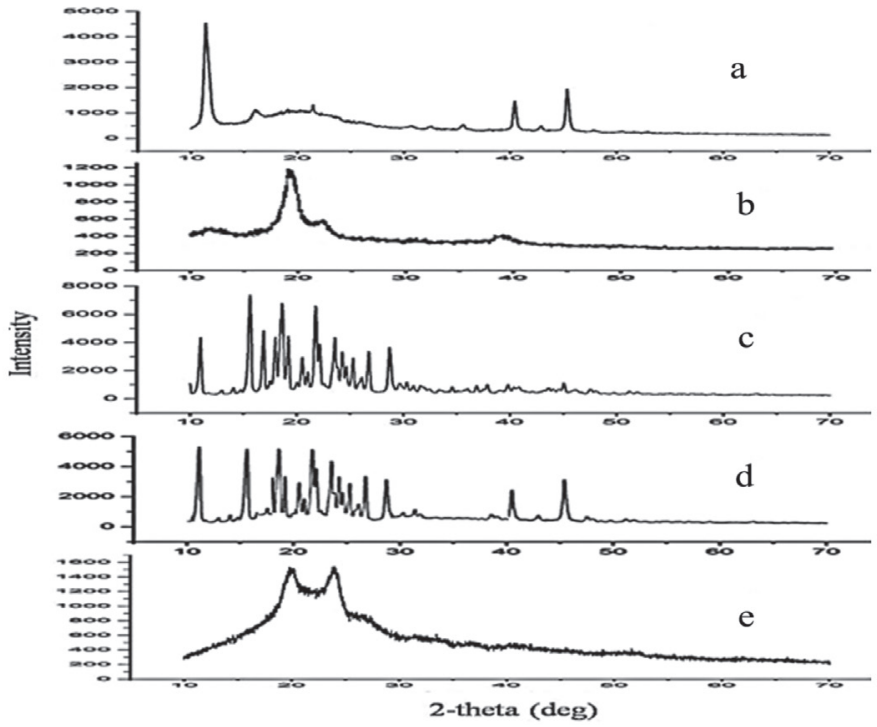

Figure 4. XRD patterns of (a) PA-F127, (b) PVA, (c) pure glipizide, (d) physical mixture, and (e) GN1

PVA: Polyvinyl alcohol, GN: Glipizide nanoporticles

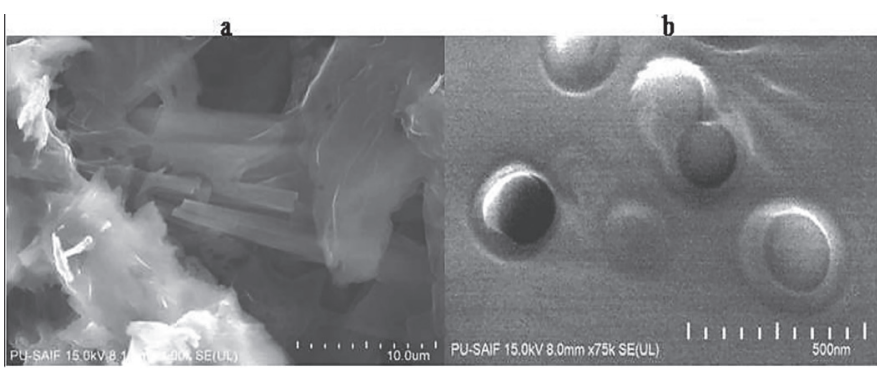

Figure 5. SEM images of (a) physical mixture (drug + excipients), (b) GN1 SEM: Scanning electron microscopy, GN: Glipizide nanoporticles temperatures ( 4 and $25^{\circ} \mathrm{C}$ ) and the results are shown in Table 3. The nanosuspension stored at both temperatures carried nanosized particles $(<250 \mathrm{~nm})$, whereas a slight increase in PDI and a reduction in zeta potential and entrapment efficiency were observed. During the storage time, no visual color change was noted. The reduction in entrapment efficiency and increase in particle size might be attributed to the semi-amorphous character of the amphiphilic PA-F127 copolymer in GN1. When the lipophilic part of a copolymer is exposed to kinetic energy (temperature or light), the semi-amorphous state changes into the more stable amorphous state, which leads to an increase in particle size and expulsion of drug from the polymeric matrix with the reduction in entrapment efficiency. ${ }^{30}$ The results of the stability studies were statistically nonsignificant. The nanoparticles stored at $5 \pm 3^{\circ} \mathrm{C}$ showed nonsignificant variation in the studied parameters, which indicates that the above temperature was the optimum storage temperature.

\section{Pharmacokinetic studies}

The mean plasma concentrations of glipizide vs. time profile adopting a single oral dose of GN1 $(1.5 \mathrm{mg} / \mathrm{kg})$ and glipizide suspension $(1.5 \mathrm{mg} / \mathrm{kg})$ in six rats is presented in Table 4 and Figure 7 . The value of peak plasma concentration $\left(C_{\max }\right)$ of GN1 was 2.35-fold higher than that of the glipizide suspension ( $p<0.05)$. The time required to reach the maximum plasma concentration ( $\left.t_{\text {max }}\right)$ after oral administration of GN1 and glipizide suspension was 6.0 and 4.0, respectively. The elimination half-life $\left(t_{1 / 2}\right)$ of GN1 was 1.5 -fold ameliorated than the glipizide suspension $(p<0.05)$. The area under the curve $\left(A \cup C_{0 \rightarrow \infty}\right)$ of

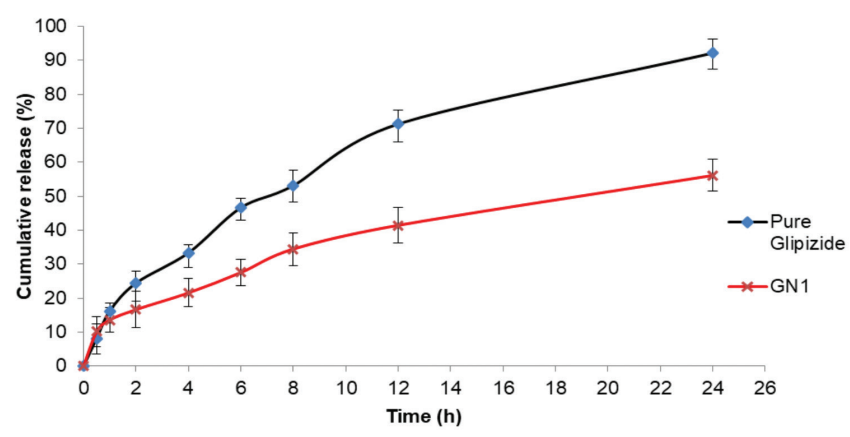

Figure 6. In vitro release profiles of GN1 and pure glipizide

GN: Glipizide nanoporticles

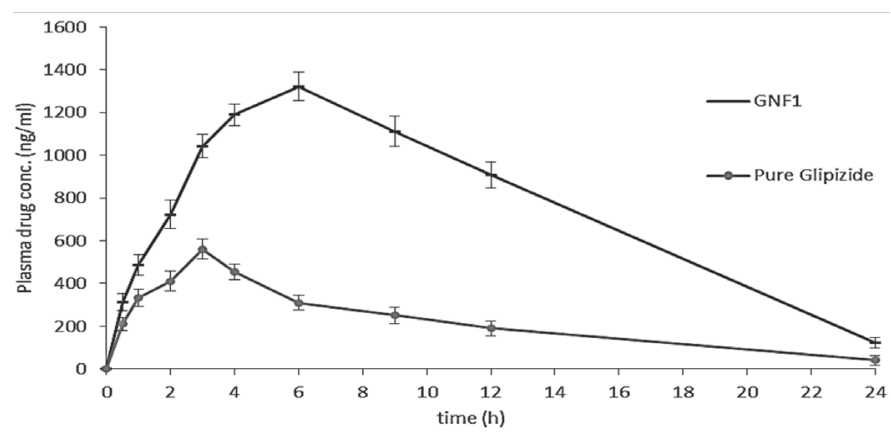

Figure 7. Mean plasma concentrations of glipizide vs time graph after single oral administration of GN1

GN: Glipizide nanoporticles 
Table 3. Stability studies of GN1

\begin{tabular}{llllll} 
Storage condition & Particle size $(\mathrm{nm})$ & PDI & Zeta potential $(\mathrm{mV})$ & Entrapment efficiency (\%) & Visual observation \\
\hline Fresh GN1 & $242.6 \pm 4.20$ & $0.171 \pm 0.01$ & $-21.41 \pm 0.462$ & $81.13 \pm 3.1$ & Clear suspension \\
\hline 1 month $\left(5 \pm 3^{\circ} \mathrm{C}\right)$ & $244.2 \pm 4.04$ & $0.171 \pm 0.02$ & $-21.20 \pm 0.472$ & $80.43 \pm 2.5$ & Clear suspension \\
\hline 3 month $\left(5 \pm 3^{\circ} \mathrm{C}\right)$ & $246.0 \pm 3.42$ & $0.184 \pm 0.03$ & $-21.01 \pm 0.522$ & $79.25 \pm 4.5$ & Clear suspension \\
\hline 1 month $\left(25^{\circ} \mathrm{C}\right)$ & $246.3 \pm 4.70$ & $0.182 \pm 0.02$ & $-20.84 \pm 0.341$ & $78.64 \pm 4.2$ & Clear suspension \\
\hline 3 month $\left(25^{\circ} \mathrm{C}\right)$ & $249.5 \pm 5.43$ & $0.196 \pm 0.03$ & $-20.35 \pm 0.52$ & $77.25 \pm 3.5$ & Clear suspension \\
\hline
\end{tabular}

$\mathrm{n}=3$, mean values \pm standard deviation, PDI: Polydispersity index, GN: Glipizide nanoporticles

\begin{tabular}{llllll}
$\begin{array}{l}\text { Table 4. Pharmacokinetic parameters of GN1 and pure glipizide } \\
\text { suspension }\end{array}$ & $\begin{array}{l}\mathrm{C}_{\max } \\
\text { Sample }\end{array}$ & $\begin{array}{l}\mathrm{t}_{\max } \\
(\mathrm{ng} / \mathrm{mL})\end{array}$ & $\mathrm{t}_{1 / 2}(\mathrm{~h})$ & $\begin{array}{l}\text { AUC } \\
(\mathrm{ng} \cdot \mathrm{h} / \mathrm{mL})\end{array}$ & MRT (h) \\
\hline $\mathrm{GN1}$ & $1321 \pm 110$ & 6.0 & $10.51 \pm 0.2$ & $18574 \pm 96$ & $11.06 \pm 0.4$ \\
\hline $\begin{array}{l}\text { Glipizide } \\
\text { suspension }\end{array}$ & $561 \pm 86$ & 4.0 & $7.04 \pm 0.1$ & $5688 \pm 102$ & $9.25 \pm 0.3$ \\
\hline
\end{tabular}

mean \pm standard deviation, n=6, AUC: Area under the curve, MRT: Mean residence time GN: Glipizide nanoporticles

GN1 was 3.3-fold higher compared to the glipizide suspension (p<0.05). Finally, an improvement $(1.2$-fold) in the mean residence time of GN1 over pure glipizide suspension ( $p<0.05$ ) was recorded. Overall, the oral bioavailability and circulation time of GN1 were improved significantly.

\section{CONCLUSIONS}

In the present investigation, GNs were prepared using the newly synthesized PA-F127 copolymer. The drug and excipients were compatible with each other. The optimized nanoparticles batch (GN1) can be best stored at $5 \pm 3^{\circ} \mathrm{C}$ without losing its properties. The ameliorated pharmacokinetic parameters of GN1 confirmed the improved bioavailability and circulation time. The therapeutic plasma concentration of drug with a single oral dose of GN1 was maintained up to $24 \mathrm{~h}$ and the problem of frequent oral dose administration ( 2 or 3 times a day) with the conventional dosage form can be overcome by the use of GN1. The reported PA-F127 pentablock copolymer could be a suitable carrier for nanotechnology-based oral glipizide.

\section{ACKNOWLEDGEMENTS}

The authors are grateful to the University Grant Commission (UGC), New Delhi, for providing a fellowship under Major Research Project (MRP) Reference No: FN/42/703/2013/SR. The authors are also grateful to the Secretary-cum-Scientific Director, Indian Pharmacopoeia Commission, Ghaziabad, for providing chromatographic facilities at the ARD Lab.

Conflict of Interest: No conflict of interest was declared by the authors.

\section{REFERENCES}

1. Lahoti SR, Puranik PK, Heda AA, Navale RB. Development and validation of RP-HPLC method for analysis of glipizide in guinea pig plasma and its application to pharmacokinetic study. Int J PharmTech Res. 2010;2:16491654.

2. Dash RN, Mohammed H, Humaira T, Ramesh D. Design, optimization and evaluation of glipizide solid self-nanoemulsifying drug delivery for enhanced solubility and dissolution. Saudi Pharm J. 2015;23:528-540.

3. Emami J, Boushehri MSS, Varshosaz J. Preparation, characterization and optimization of glipizide controlled-release nanoparticles. Res Pharm Sci. 2014;9:301-314.

4. Ammar HO, Salama HA, Ghorab M, El-Nahhas SA, Elmotasem H. A transdermal delivery system for glipizide. Curr Drug Deliv. 2006;3:333341.

5. Patel JK, Patel RP, Amin AF, Patel MM. Formulation and evaluation of mucoadhesive glipizide microspheres. AAPS PharmSciTech. 2005;6:4955.

6. Naha P, Byrne HJ, Panda AK. Role of polymeric excipients on controlled release profile of glipizide from PLGA and Eudragit RS 100 nanoparticles. J Nanopharm Drug Deliv. 2013;1:74-81.

7. Huang $H$, Wu Z, Qi X, Zhang $H$, Chen $Q$, Xing J, Chen $H$, Rui $Y$. Compression-coated tablets of glipizide using hydroxypropylcellulose for zero-order release: In vitro and in vivo evaluation. Int J Pharm. 2013;446:211-218.

8. Nie S, Zhang S, Pan W, Liu Y. In vitro and in vivo studies on the complexes of glipizide with water-soluble beta-cyclodextrin-epichlorohydrin polymers. Drug Dev Ind Pharm. 2011;37:606-612.

9. Kulkarni N, Wakte P, Naik J. Development of floating chitosanxanthan beads for oral controlled release of glipizide. Int J Pharm Investig. 2015;5:73-80.

10. Mahesh KV, Singh SK, Gulati M. A comparative study of top-down and bottom-up approaches for the preparation of nanosuspensions of glipizide. Powder Technol. 2014:256:436-449.

11. Soppimath KS, Aminabhavi TM, Kulkarni AR, Rudzinski WE. Biodegradable polymeric nanoparticles as drug delivery devices. J Control Release. 2001;70:1-20.

12. Gao Q, Liang $Q$, Yu F, Xu J, Zhao Q, Sun B. Synthesis and characterization of novel amphiphilic copolymer stearic acid-coupled F127 nanoparticles for nano-technology based drug delivery system. Colloids Surf B Biointerfaces. 2011;88:741-748.

13. Kamboj VK, Verma PK. Poloxamers based nanocarriers for drug delivery system. Der Pharm Lett. 2015;7:264-269.

14. Xiong XY, Li YP, Li ZL, Zhou CL, Tam KC, Liu ZY, Xie GX. Vesicles from Pluronic/poly(lactic acid) block copolymers as new carriers for oral 
insulin delivery. J Control Release. 2007;120:11-17.

15. Dhanalekshmi UM, Poovi G, Kishore N, Reddy PN. In vitro characterization and in vivo toxicity study of repaglinide loaded poly (methyl methacrylate) nanoparticles. Int J Pharm. 2010;396:194-203.

16. Patil P, Bhoskar M. Optimization and evaluation of spray dried chitosan nanoparticles containing doxorubicin. Int J Curr Pharma Res. 2014;6:715.

17. Lokhande A, Mishra S, Kulkarni R, Naik J. Formulation and evaluation of glipizide loaded nanoparticles. Int J Pharm Pharm Sci. 2013;5:147-151.

18. Rani R, Dahiya S, Dhingra D, Dilbaghi N, Kim KH, Kumar S. Evaluation of antidiabetic activity of glycyrrhizin-loaded nanoparticles in nicotinamidestreptozotocin induced diabetic rats. Eur J Pharm Sci. 2017;106:220230.

19. Mutalik S, Udupa N, Kumar S, Agarwal S, Subramanian G, Ranjith AK. Glipizide matrix transdermal systems for diabetes mellitus: Preparation, in vitro and preclinical studies. Life Sci. 2006;79:1568-1577.

20. Duarah S, Pujari K, Ghosh J, Unnikrishnan D. Formulation and evaluation of metformin engineered polymeric nanoparticles for biomedical purpose. Res J Pharm Biol Chem Sci. 2015;6:1005-1019.

21. Birnbaum DT, Kosmala JD, Brannon-Peppas L. Optimization of preparation techniques for poly(lactic acid-co-glycolic acid) nanoparticles. J Nanopart Res. 2002;1:173-181.

22. Jain S, Saraf S. Influence of processing variables and in vitro characterization of glipizide loaded biodegradable nanoparticles. Diabetes Metab Syndr Clin Res Rev. 2009;3:113-117.

23. Kusum VD, Bhosale UV. Formulation and optimization of polymeric nano drug delivery system of acyclovir using 32 full factorial design. Int $\mathrm{J}$
PharmTech Res. 2009;1:644-653.

24. Mukherjee B, Mahapatra S, Gupta R, Patra B, Tiwari A, Arora P. A comparison between povidone-ethylcellulose and povidone-eudragit transdermal dexamethasone matrix patches based on in vitro skin permeation. Eur J Pharm Biopharm. 2005;59:475-483.

25. Mukherjee B, Santra K, Pattnaik G, Ghosh S. Preparation, characterization and in vitro evaluation of sustained release protein-loaded nanoparticles based on biodegradable polymers. Int J Nanomed. 2008;3:487-496.

26. Ramazani A, Keramati M, Malvandi $H$, Danafar $H$, Kheiri Manjili $H$. Preparation and in vivo evaluation of anti-plasmodial properties of artemisinin-loaded PCL-PEG-PCL nanoparticles. Pharm Dev Technol. 2018;23:911-920.

27. Dash RN, Mohammed H, Humaira T, Reddy AV. Solid supersaturatable self-nanoemulsifying drug delivery systems for improved dissolution, absorption and pharmacodynamic effects of glipizide. J Drug Deliv Sci Technol. 2015;28:28-36.

28. Mokale V, Rajput R, Patil J, Yadava S, Naik J. Formulation of metformin hydrochloride nanoparticles by using spray drying technique and in vitro evaluation of sustained release with 32-level factorial design approach. Dry Technol. 2016;34:1455-1461.

29. Lekshmi UM, Kishore N, Reddy PN. Subacute toxicity assessment of glipizide engineered polymeric nanoparticles. J Biomed Nanotechnol. 2011;7:578-589.

30. Elbahwy IA, Ibrahim HM, Ismael HR, Kasem AA. Enhancing bioavailability and controlling the release of glibenclamide from optimized solid lipid nanoparticles. J Drug Deliv Sci Technol. 2017;38:78-89. 